\title{
Anthrovision
}

Vaneasa Online Journal

Vol. 7.2 | 2019

Epistemic Disobedience

\section{Image as a Weapon:}

Videography of the Encounters, Methods of Visual Ethnography

Sophia Ferreira Pinheiro and Patrícia Ferreira Pará Yxapy

\section{(2) OpenEdition}

Journals

Electronic version

URL: http://journals.openedition.org/anthrovision/5602

DOI: 10.4000/anthrovision.5602

ISSN: 2198-6754

Publisher

VANEASA - Visual Anthropology Network of European Association of Social Anthropologists

Electronic reference

Sophia Ferreira Pinheiro and Patrícia Ferreira Pará Yxapy, "Image as a Weapon:", Anthrovision [Online], Vol. 7.2 | 2019, Online since 10 November 2020, connection on 26 January 2021. URL: http:// journals.openedition.org/anthrovision/5602 ; DOI: https://doi.org/10.4000/anthrovision.5602

This text was automatically generated on 26 January 2021.

(c) Anthrovision 


\title{
Image as a Weapon:
}

Videography of the Encounters, Methods of Visual Ethnography

\author{
Sophia Ferreira Pinheiro and Patrícia Ferreira Pará Yxapy
}

\section{Introduction}

1 In this article, we will explore a relationship between Patrícia Ferreira and Sophia Pinheiro through image and filmmaking. A videography of a poetic encounter between two women, one indigenous and other non-indigenous, using visual anthropology in a delicate sense, we approach the methodological processes of my master's research which was centered on the images and trajectory of Patrícia Ferreira Pará Yxapy as an indigenous filmmaker ${ }^{1}$. In this research, the images not only fulfill the function of documentation, "proof that the anthropologist was in the field", but acquire a fundamental role as the methodological process of research through a visual ethnography that imagines the power of the images as a production of meaning.

2 In the master's dissertation "The image as a weapon: the trajectory of indigenous filmmaker Patrícia Ferreira Pará Yxapy" (2018), the filmmakers' trajectory and cinematographic works were investigated, linked to the context of contemporary indigenous cinema made by women in Brazil. Patricia is ethnically Mbyá-Guarani, a school teacher for the children of the village where she lives, in Ko'enju ${ }^{2}$, and is currently considered the most relevant woman in Brazilian indigenous cinema. I attempted to understand the trajectory of Patricia from the relations she establishes with the images to the appropriations of her speeches, undertaking her own artistic agency in the production of female indigenous cinematography. It was from this aesthetic fissure that we created an ethnographic experience of video-letters, a method that consists in the exchange of videographic messages of the most diverse subjects. The poetic result of these exchanges of images. where one films the other, displays our relationship with images and sounds. Through the images, our relationship became closer and compassionate - sensitized and composed of affections. We made our film Teko Haxy - Being Imperfect ${ }^{3}$ (Brazil 2018), with some of the filming we did during the 
master's research process. The following are some of our filming processes, techniques, and parts of the videos that make up our movie.

We accomplished a "multisituated field" (Marcus 1995), a notion produced from the new dynamics of the contemporary world. Our images were made in three distinct Mbyá-Guarani villages: Ko'enju, in São Miguel das Missões (RS/Brazil), Kunhã Piru, and Tamanduá, both in the province of Misiones, Argentina. We also made our images in transit, because we traveled together a few times. It was on one of those trips that Patricia adopted me as her younger sister. Our relationship went beyond research and today we are friends. The unfamiliar has become very "familiar" to me.

This article was written by both of us, but sometimes Sophia writes in the first person because we decided that she works as a "curator" of these passages and because she has more "patience with academic writing and the way the juruá (white) think", as Patrícia says. Furthermore, we think that the text becomes more fluid and intimate - which is how we analyze our relationship with images. Patrícia's words and the terms in the Mbyá language will be transcribed in italics.

\section{Our Relationship Through Images}

role of art as a tool for achieving not only social demands but also visibility for themes of community and political interest, makes the old companionship between art
and politics come into play. The fieldwork of the researcher became a transdisciplinary area with a strong influence of the tools and methodologies proper to anthropology, thus proposing a new paradigm for the artist's intervention. Ethnography is in constant movement between cultures (Clifford 2008). Perhaps it was this inherent characteristic of ethnographic practice, intercultural displacement, which aroused the interest of artists and triggered what Foster (2017) says is a kind of envy, first by the artist, by this logic, and later, of the ethnographer in relation to the artist when he began to reinvent ethnographic methods.

The writing of letters and diaries played an important role in the development of women's literature in times of profound repression, when women who had the privilege of knowing how to write could not publish books; they were anonymous writers or created male pseudonyms to have their writing legitimized. Letters and diaries were spaces where these women, removed from the dominant genres of literature, could write what they thought - and what was not allowed. And, of course, let's not forget about field diaries in anthropology. Letters and diaries were also important, at that time, for housewives without literary pretensions, as just a safe space to meet their inner selves. Perhaps it is through the writings of oneself that epistolary cinema is anchored in the relationship between correspondents, making correspondence a cinematic form of oneself, within the daily film and the video letter genres. According to Roberta Veiga and Carla Italiano (2015), "thinking about the diary as apparatus allows us to delimit certain filming strategies, through which subjectivity is built in its form of approach and relationship with the world and with otherness".

9 The imagery process is given as an instrument of transmission of the alterity in which these relations are stablished, because they produce and reproduce ideas. Image is 
polysemic: on the one hand, it has the capacity to evoke and elucidate things that text cannot express, on the other, it is too open and needs a verbal discourse to direct the view, the interpretation, in the sense of the discussion that the researcher wants to develop. In addition, the image is polyphonic because it contains not only several voices but different shared views. In this sense, we think that the realization of an ethnographic research combined with the production of shared intersubjective images, that is, images produced in common or by ethnographic self-representation, enable a greater discursive communion, an engaged anthropology (Fabian 2001) with the place of speech transferred to the same historical time and space of the other that comes out of its objective condition, becoming a partner in the construction of knowledge.

The filmmaker and anthropologist Trinh T. Minh-Ha, in her film Reassemblage - from the firelight to the screen (1982) ${ }^{4}$, shows that the important thing is not to speak about but speak nearby. To speak with and to speak next is to try to turn the "I speak about him to us" into "he and I speak of us to you" (Caiuby Novaes 2012: 24). Therefore, this shared view (Fabian 2001, 2013) and the relation between the images is what we aim for with the video-letters.

11 Cinematographic writing is done regardless of whether a person directs someone or not, in a context of a greater movement of establishing a relationship. We establish this relationship, a movement of the body and affections, a meeting of the human.

\section{Image as Multiple Weapons: Agencies and the Construction of an Indigenous Trajectory}

12 The hunting of images, the pursuing of self (self-representation and self-esteem) combined with the use of hunting power, that is, the empowerment of carrying equipment, not only technical knowledge but also production for registration, denunciation, document, and represent otherness, all this are evidence for the metaphor of image as weapon used in this article. The gesture of shooting and filming is the hunter's gesture, as the philosopher Vilém Flusser states (1985). Jean Rouch in an interview in July 1973, makes an analogy with the camera-gun, an aspect relevant to cine-trance, proposed by him:

To prepare a documentary on lion hunting I spent a long time in an African village. Filming took place over a period of about six years. For the people of this village, cinema has become something familiar. After this first film about the collective hunting of the lion, they asked me to regularly film the hunts. Making several films on the same subject to them is absolutely natural and a hunt without the presence of the camera is no longer good. Cinema became part of the ceremony; the camera, a weapon for hunting. (Jean Rouch, in testimony to José Carlos Avellar, 1973).

13 The ciné-transe photographic/filming expression has the power that sometimes transforms the camera operator into a mechanical eye or electronic ear (Sautchuk 2013). McLuhan (1974: 383), in the book "Understanding Media: The Extensions of Man", talks about technologies and the media as extensions of man, alluding to the camera and weapon as extensions of the eye: "If the arrow is an extension of the hand and arm, the shotgun is an extension of the eye and the teeth". McLuhan (1974: 383) also makes an analogy between the emergence of the firearm and the perspective, since it is the aim ${ }^{5}$, the target, "as well as the extension of visual power in literacy and written culture". According to Sautchuk: 
The intention is not to suppress the camera or to tame it completely so that it does not cause noise in the direct relations between humans. On the contrary, it assumes that it transfigures the ethnographer (and the filmed) into something else, and, from this, puts it in a position to establish relations of meaning, not with the individuals exactly, but with the processes that are developing (possession, colonialism, hunting, etc.) (Sautchuk 2013: 26).

Patrícia learned to film in the workshops of Vídeo Nas Aldeias (VNA) ${ }^{6}$ without a tripod, the camera hand-held. This more intimate contact with the camera makes her filming style more intimate, closer, most often with close-up shots. Vincent Carelli and Ana Carvalho (from the VNA project) explained, in November 2016 in Olinda, that during the workshops, the project does not recommend using the tripod precisely to obtain more participative, personal plains, a film that accompanies the people who are being filmed, even when seated. This recommendation mainly seeks to prevent them from getting too comfortable with using the tripod. In the workshops, the indigenous people are alerted when their images are out of focus, changes to light and contrast because of the movement or are very shaky and without image stabilization. In this way they are taught to improve their process of capturing images with the camera in hand. It is known that filming this way leads to a much more intense relationship between the person and the camera. There is actually a corporeal coupling in which the body itself is a filming instrument as it plays a role similar to that of the tripod and becomes an extension of the camera through the eye.

Patricia with the equipment used in our video-letters

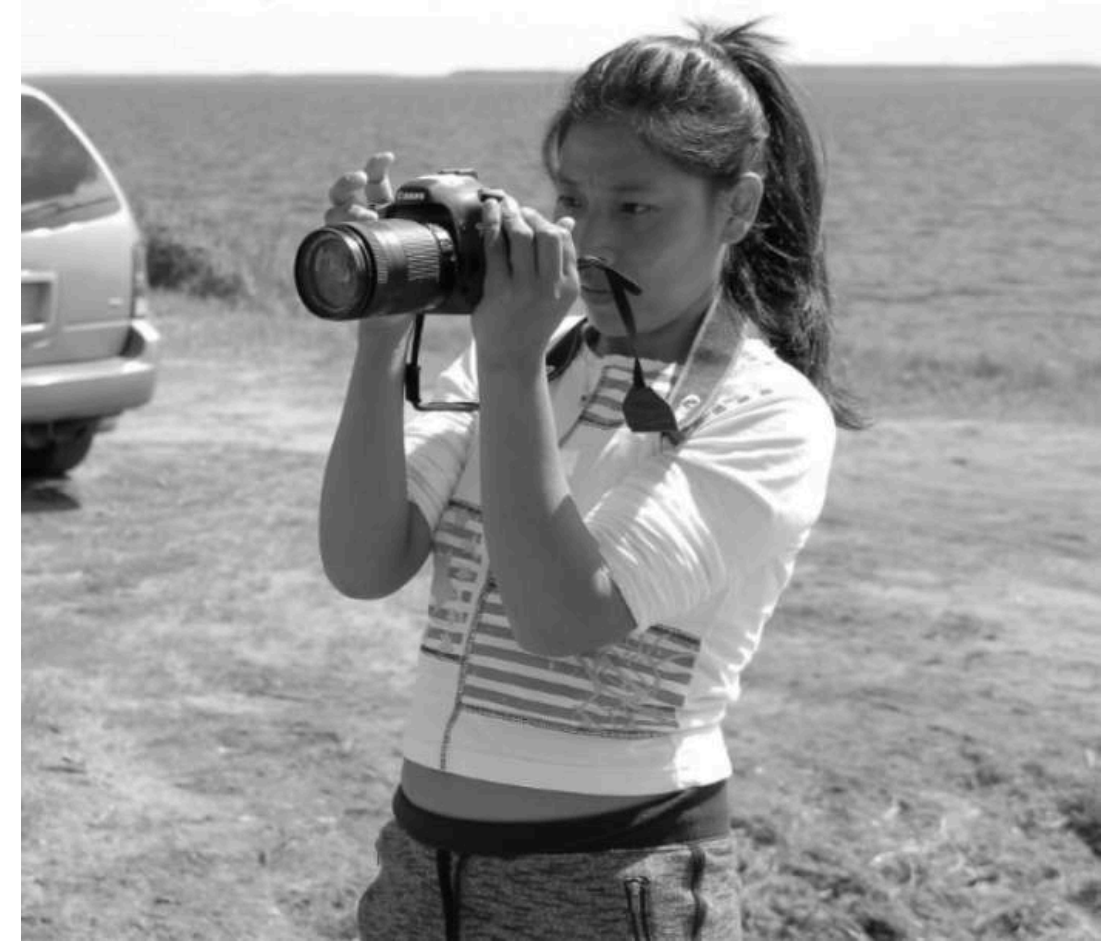

Photo by Sophia Pinheiro 2016.

The body as an instrument of filming brings the camera in this movement as a multiple use weapon. The importance of the process of realization of these images captured by the body-camera-weapon involvement encompasses the relationships that can be 
created. The camera is with the people filmed and/or photographed and with the operator, it does not operate above them. The relations of knowledge, affection, resistance, and militancy (for example, during a protest in Funai ${ }^{7}$, the camera was used alongside the body), in short, the relations that this device adds are participatory something common also in the indirect documentary. It is participations that involve improvisations and implications, that make the camera a weapon of knowledge. Sautchuk also points out:

It is precisely in camera movements and involvement with the activities of those being filmed that Rouch (2003) sees the emergence of its creative (and epistemic, we might say) effect, when the camera can incite hunts or become part of ceremonies, and even trigger off trance. But this participation, involving commitment and improvisation, has its counterpart in the handling of the camera as a technical device, which turns it into an instant form of knowledge, that is, it demands syntheses, approaches, distancing, as it observes. We could see in these aspects a fertile connection between the notions of Rouch's camera and Ingold's weapon $(1986,2000)$ - both refer to an utterly transformative technical coupling that, however, requires a dynamic tie with the movements of those with whom it is related, and operates via in situ syntheses. For Ingold, the weapon does not capture an animal, but rather reveals a world, because it is a perception and knowledge device. (Sautchuk 2013: 26).

16 There are many accounts of the first contacts of traditional peoples through the lenses of film and photo cameras. In these contacts, the fear of the equipment refers to the comparison of the camera to a weapon pointing at the target. The very gesture of capturing images can be confusing because "the operator" searches for what to capture (picture) through the viewfinder. The camera-gun is a device that shoots. It activates, finally, the "gesture of photographing". One last decision is made: squeeze the trigger. According to Flusser:

Such considerations allow us to summarize the characteristics of the gesture of photographing: it is a hunter gesture in which the apparatus and photographer are confused, to form an inseparable functional unit. The purpose of this unified gesture is to produce photographs, that is, areas in which scenes are symbolically created. (Flusser 1985: 20).

17 At the same time, the images of first contact want to bring close who's far away, that is, to integrate the isolated one into modern society, to bring him into the Juruákuery (white people) world. The camera's image is a western knowledge and framing a people with its lens, is framing them in this certain knowledge. In this article, we think of image as a weapon in three ways: 1) as a weapon of record, documentation and denunciation - of the violence committed by non-indigenous society; 2) as a weapon to sensitize western views and life practices, through otherness and 3) as a process of educating political leaders through artistic practices (cinema, audiovisual, visual arts, theater and literature, for example). Regarding this camera as a weapon of creating a visible scenes, in a debate Patrícia presented the filmmaking process of her new feature. During the "Mostra Olhar - Um ato de resistência"s in 2015, she stressed:

Dreams and words have to touch our hearts. My Grandmother says that there are few people who have this gift of touching the heart. These words are poetic, this is why I want to touch your heart with these movies. I want them to be like an arrow in your heart.

18 The arrow is a weapon used to reach a distant target, in the case of Patricia, to reach the Juruákuery (white people) who are distant. It is an attempt to bring them together and raise their awareness of the Mbyá worldview. By overcoming this spatial distance from the image as an arrow towards the non-indigenous heart, this metaphor 
elaborates, dialectically, not only the camera but also image itself as a weapon. In addition to this performance of technique, perception, and knowledge of the camera as a multiple weapon, we understand the images resulting from this process also with multiple relationships, especially the image as a weapon of struggle. Mainly of the struggles in favor of indigenous rights: to assist in the struggle for land, in the requisition of belonging and in the fight against racism, sexism and other social inequalities. The self-image has the possibility to demand the historical protagonism that the indigenous population deserves. In this way, we believe that metaphorically, indigenous filmmakers are "cannibals"s of imaging methodologies and techniques, for their own ethnogenesis. For our work, the images are also a way of arming ourselves with self-preservation, spirituality, and self-knowledge.

\section{Methodologies of Epistolary Cinema}

19 Natuyu Txicão, co-director of the film Das Crianças Ikpeng Para o Mundo (Brazil 2001) (Natuyu Yuwipó Txicão, Karané Ikpeng and Kumaré Ikpeng 2001), shows in this cinematic experience four Ikpeng children who present their village responding to a video-letter from the children of Sierra Maestra in Cuba. Curious about meeting children from other cultures, they ask the other children to respond to their videoletter. In an analysis of the film, Ruiz (2009: 64) refers to the extracampo - in this case, the "out of frame" - constituted by the film in the form of video letters: when the children talk to the viewer, "the composition of cinematic space extrapolates the relation between what is inside and outside the frame, that is, it is no longer restricted to the universe represented in the film, including by us the spectators, in the very structure of the documentary." By incorporating into the video a third space - the universe of the viewer - "as a constituent part of the cinematic space, locating it in the center of a triangulation between what we see on the screen, what we know to be next that which we see, and ourselves" (Ruiz 2009: 64), the viewer becomes an invisible part of the film narrative and also a character, participating in the game of questions and answers elaborated by the structure of the video-letter.

In "Olhar: um ato de resistência", a film program in Forumdoc.bh documentary film festival and forum, in 2016, during a panel that brought together indigenous filmmakers from some parts of the world to discuss policies for the diffusion and consolidation of work, some of them suggested video-letters who were aware of a project initiated in Cuba and which had gone to Bolivia. They said that they would be happy to see the exchange processes between indigenous people in different parts of the world and that these processes would encourage the creation of networks among indigenous filmmakers. They gave the example of being able to see what Patrícia's village is like, and for her to see what someone else's village looks like, and that circulations could be made over the internet, on Facebook.

During our creative process making the video-letters, I attended a screening of correspondence films during the Doclisboa'16 film festival, held in Lisbon, Portugal in October 2016. At the showing, films like Life May Be (2014) by Mania Akbari and Marks Cousins, and Mona Hatoum's Measures of Distance (1988), instigated me for her provocative themes of distances and affections, intimacy, and bodies. Curiously, the program was mostly composed of video-letter films made by women. 

with Vincent Carelli that inspired the founding of Vídeo Nas Aldeias, the video would be used to create a network of dialogue among diverse indigenous ethnic groups, as Carelli (2017) states in the "Andrea Tonacci Dossier" of Abraccine :10 "Andrea was very enthusiastic about the beginning of this new work: how would be the view of the Indian. He began a tour in 1978 of the United States, Peru, and Brazil, filming black and white messages from one people to another". Thus, the process proposed by Inter Povos would be what is now understood as video-letters, that is, this methodological instigation initially encouraged the creation of these two projects relevant to the exchange, use, and production of images by Brazilian indigenous peoples. who uses the method as one of the exercises in the project Inventar com a Diferença. The author emphasizes the horizontality of the relations between the subjects so that the methodological practice is established in a dialogical way and opens a the multiplicity of recipients that cinema possesses virtually: "The film-letter thus has a relevant aspect in the challenges of teaching: without a viewer we do not stay, it exists, virtually, even if the letter is never opened" (Migliorin 2015: 158). The video-letters go from the director to the recipient - often the directors themselves are the target audience, becoming spectators inserted into that conversation established by the images. Migliorin (2014) still evokes the tradition of the film-letter as a cinematographic method, fragile and heterogeneous, a tradition that includes works by directors such as Chris Marker (Lettre de Sibérie 1957), Jonas Mekas (Correspondance Mekas - J. L. Guerin 2011), Abbas Kiarostami (Victor Erice/Abbas Kiarostami: Correspondances 2007), Agnès Varda (Ulysses 1982), Jean-Luc Godard (Letter to Jane 1972), Chantal Akerman (News from Home 1977), Eric Pawels (Carta de um cineasta a sua filha 2000), Robert Kramer (Dear Doc 1991), David Perlov (Diary 1973-1983).

In their differences, the films and filmmakers above, with their essays and filmletters, allow the assembly of central elements in the studies and the challenges of cinema: the performance, the off, the field/off-field, the visible/not visible, articulated by the assembly and the frame; the chronological or non-measurable velocities; the narrative and the progressions, the strangeness and the reflexivity, the suspension, the detachment; the relationship with the other. (Migliorin 2014: 12).

Thus, by putting our artistic work in relation to each other, we produce collective images and perspectives, creating a possible double field by means of our conversations, images and all the outer fields that Patricia's aesthetic decisions evoke through her Mbyá-Guarani culture. By exposing the process, we also expose our performance before the camera, our voice recorded offscreen, what is in front and not in front of the camera, the visible/not visible, the duration of the shots and the timing of filming, intrinsic - in our experience - to how to film the estrangement and reflexivity, the suspension, the detachment, and who we are.

The first time we talked about the idea of using the video-letters, Patricia said: "I have never worked with, nor sent video-letters to anyone, you (Sophia) would be the first one to present the idea to $m e "$. Because of this, we watched the film Cartas para Angola (Brazil 2012) (Coraci Ruiz and Julio Matos 2012) in the village of Ko'enju, so I could show her how this practice works and its potential. After watching the film, we also watched other projects that use video-letters in support, such as the affective-poetic independent project "Um dia você me manda uma carta", which proposes to (re) 
produce video-letters made and scattered around the world. We talk about the letters of Van Gogh sent to his brother Theo, the letters of illustrator Margaret Mee and, of course, the video-letter made by Natuyu Txicão and some of the videos of the Women's Association of Xingu with the Catitu Institute. When Patricia saw that the Xinguan women cut the children's umbilical cord bamboo, she said: "We also do it like that!". In 2016, we watched the video installation Ymá Nhandehetama (Brazil 2009), by the artist Armando Queiroz and the native Guarani Almires Martins ${ }^{11}$. Patricia felt deeply touched by the video of Almires, as she told me, and from then on, I believe she was able to understand more of the proposition "that I presented." These were some references that I showed to explain the proposal and Patricia visually understand what until then we only talked about verbally:

For me, in our process, I realized two things: one about the spiritual process and another is the different view of on things we had. Broadly, there was a different view, and I think I had to work a little harder to understand what was going on ever since you told me about the video-letters and the work. Because on the one hand, there was a person with juruá (white) thought and I with my Mbyá thoughts. Especially when I understood the nature of the body of work, I went one step further in my growth and we were putting our personal experience into this work. (Patricia Ferreira Pará Yxapy, 2016)

After seeing these images, Patricia understood better and thought the idea was cool. Even if I hadn't proposed it, she had already thought of doing it with an Inuit from Canada. During my fieldwork in June and July of 2015, Patricia had a cell phone to start exchanging some video-letters, and in August of that year she traveled to another artistic residence in Canada and continued to send video-letters and photographs to me.

\section{"Where my feet trod"}

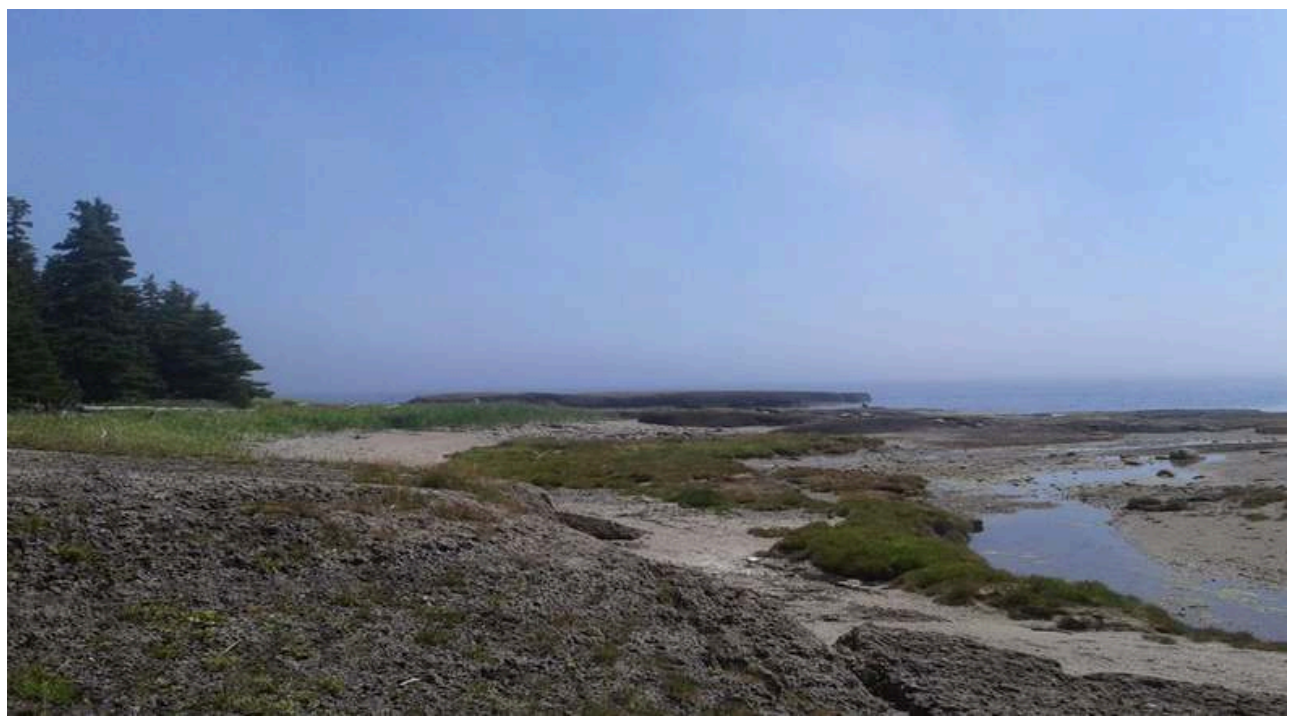

Patrícia's caption for the photograph. This is the first image the video-letters sent by Patricia from Canada.

Photo by Patrícia Ferreira Pará Yxapy 2015.

In order to make the proposal feasible, we decided to submit the video-letters as a cultural project in the Edital do Fundo de Arte e Cultura do Estado de Goiás ${ }^{12}$, in the area of Visual Arts called Creation of Unpublished Works. The work was financed by the Fundo de Arte e Cultura do Estado de Goiás and, from May to June of 2016, we began to execute it. 
The cultural project also financed the purchase of equipment for Patricia and the Mbyá-Guarani Cinema Collective - this was an internal demand of the collective - to enable the filming and photography of the project and to have their proper equipment, enabling them to create future projects and the beginning of the long dreamed of audiovisual laboratory in the village.

\section{Research Techniques in the Discussion of Constructing Images}

In communion with the way Patrícia was taught to film in the methodological proposals of the VNA workshops, which according to her, go through a process of visual references - watching films and sometimes producing everyday situations - initially without a script but with predetermined themes, we created some points that we could discuss and show in our film. Initially, we tried to exchange some video-letters when I was in Goiânia ${ }^{13}$, showing my day to day life. We talked a lot via Facebook and exchanged some images; we were sending more photos but we could not maintain an effective video message exchange system.

In this way, we realized that only by being in the village could we execute the methodology to our satisfaction. However, some questions disturbed us, such as: If there is no distance between us, is it still a video-letter? If it's not a dialogue, with a question-and-answer video - just like Natuyu's movie - does it still fit the methodology? Over time, we put those issues aside and focused on deepening our long distance relationship with internet conversations and thinking about topics that we could discuss visually when we were together. Filming in the field, I realized that with the daily demands within the village, it would really be very difficult to take the time to do this if we were not dedicated exclusively to that purpose. Therefore, we verified that this other time lived in the village interfered in the conception of what would be the methodology, that is, the distance.

However, this does not rule out all process of in the completion of the work and its final result. Therefore, we would not make videotapes with me showing the life in the city and Patricia showing her life in the village; our conversations through the images would be together, dialogically at the same time and space in order to establish connections between the two of us, from inside/outside and the same/different. As we said, at first, we thought we would be exchanging these images from a distance, one filming "from here" and the other filming "from there", and then we would post those videos on some platform where we could watch them (Vimeo, Dropbox, or even WhatsApp) and build our relationship with our video-letters. We were mistaken, nothing that we had thought would happen happened, and we were surprised by chance, by the change of the process, and by the very way that life that dictated rules of this "game".

31 At first, I was frustrated because I thought the methodology would not work and I now realize how much this feeling of impotence was crucial so that I could learn from Patrícia about her time and the Guarani silence. We were distressed to achieve the result not just from the research methodology, but from the social project that was approved in which demanded of us an "artistic product". We then decided to take the video-letters to the field, in the village, and shoot with the two of us co-present, in time 
and space. Before I went to the village for the second time, we drew up the first drafts that were discussed between us, about what we wanted to talk about and film. Eventually, we came up with the following themes:

1) Body: sexuality, menstruation, aesthetic standards, an anthropological exercise of Patricia asking me how I see myself represented by the white body. Does that also affect you? What are the "aesthetic standards" that are on us? We filmed our bodies.

2) Love relationship: jealousy and insecurity, aging, marriage, desires, and sex.

3) Maternity: child rearing, physical and alimental restraints, Patricia's maternity and abortion (spontaneous and desired).

4) Our relationship: the first time we met and how she came to see me over time.

5) Politics: the rights of Mbyá-Guarani women not recognized by the State.

6) Letters: Patricia's letter to Pero Vaz de Caminha, European colonization, and current indigenous issues. Letter to Géssica (Patricia's daughter) in the future.

\section{Technical Devices}

Sautchuk (2013) considers the use of imaging devices more as a mode of ethnographic relation than as a means for the presentation of its results. In his research he developed an ethnographic approach through the operation of image production devices, in particular, the video camera, showing the greater importance of the visual ethnographic process of his research to the detriment of the result: "I take images as process rather than as products because, since the beginning of my research, video recording stood out as a potent medium to build ethnographic engagement and to understand the meaning of relationships between beings and things in that Amazonian context" (Sautchuk 2013: 8).

For Berger (2005), what is at stake is not so much the result - a line drawn - but the process lived: what the designer sees and knows from the experience of drawing on paper (Kuschnir 2016). Time is lengthened by the observer's immersion in a relationship with who (or what) they observe (Berger 2005). To make an analogy of drawing to the camera, to emphasize the process, is that we focus on a participatory camera (as participative ethnography), a perspective that was not difficult to execute precisely because that is how Patrícia films.

For our filming, we used an iPhone 5s, two Canon cameras, a T3i (mine) and a T5i (acquired by the project and given to Patricia), and two 35mm analog cameras, an Olympus Trip and a Canon Prima Junior DX. Some images were made during the day and watched at night, similar to the process of VNA; some scenes were agreed and negotiated following our themes and others not - I will approach our production of images below. Taking the analog cameras was a great adventure, first because I taught some of the peculiarities of the equipment to Patricia - how to insert the film, for example - and secondly because I left it with her and the children at the school so they could take pictures. And, of course, the unpredictability of analog equipment always makes the result a surprise, since you can not see how the picture was taken, and often it may not be realized (it can be overexposed or lose focus and framing). It is always a surprise the magical and confidential moment (Samain 2016) of the $35 \mathrm{~mm}$ film's revelation, the photos that might not be "good" reveal nicely, while the photos thought 
about ahead of time, and performed, sometimes do not work. Even if you have a lot of control of the technique, for me it's the same as working with luck.

Analogue photography of Patricia and Ariel, her companion.

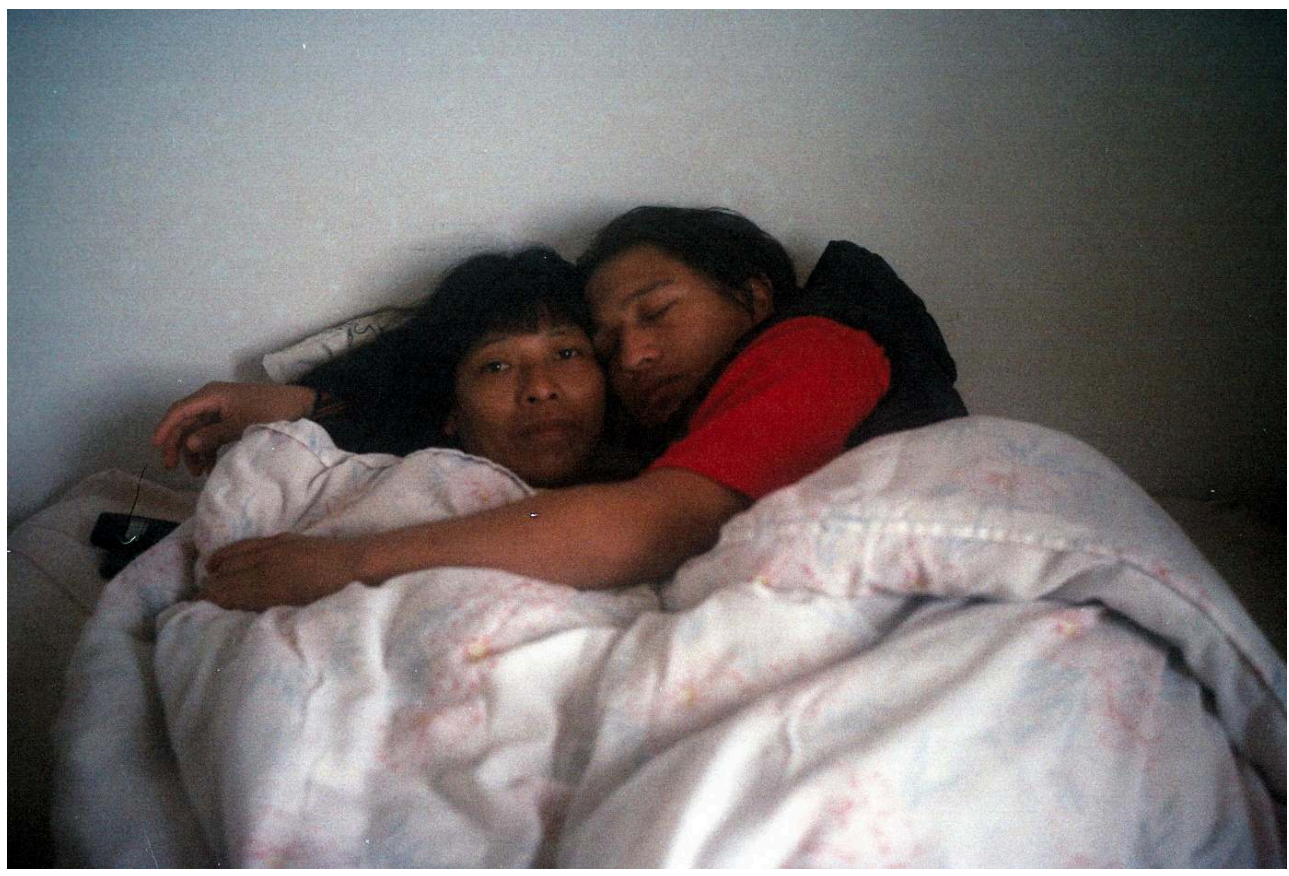

Photo by Sophia Pinheiro 2016

41 Thinking of an analogy of drawing as photography, since drawings also played a fundamental role within my ethnographic and imaginary field:

Yes, and I learned many things about drawing with you, that's what I was most interested in. I learned to draw on the computer, I learned how to make a flipbook, we made stamps and shirt prints. For example, after we worked in the school with the children together (we did exercises to create new animals for new worlds) I always use that idea with the children again. I always repeat in the classroom. (Patricia Ferreira Pará Yxapy, 2017)

Grimshaw and Ravetz discuss these approaches as a reflection that equates the process of filming with that of drawing:

To see the process film as analogous to drawing is to understand it as a means of 'knowing with' rather than knowing about. But we acknowledge that where Ingold and Taussig reject the frame wholesale, the act of filmmaking confronts us with the frame. The work of Marshall, Rouch, and MacDougall (and our own) can be understood as drawings in Ingold and Taussig's terms - traces of an embodied camera drawn into the world. Indeed, we have argued that unlike Mead's anthropology, their framing is mobile and occurs from a fluid and situated perspective. Yet in emphasizing these qualities we have also wanted to hold onto the dialectical struggle between open-ended ways of moving fluidly with experience and selective acts of framing that experience. It is precisely this dialectical tension that generates heightened consciousness and new ways of knowing. (2015: 28).

Such reflection interests me precisely because of my research with both practices, and the notion of the embodied camera drawn into the world translates many of these uses to me. Owning a embodied camera reminds me of the Slovenian photographer Evgen Bavcar (2003), when he writes that photography is a writing made of light - from this perspective, we can also draw, that is, draw strokes with the camera. The body, above 
all, performs these two procedures: by carrying the camera and pencil, the hands operate both, making them almost an extension of the body. As a response to Ingold (2013), Grimshaw and Ravetz (2015) designate the contribution of drawing to anthropology by emphasizing the fact that the film inevitably commits itself to framing while drawing remains open. On the other hand, even the observative or ethnographic drawling already have a framework of what we want to show, the action and the fabrication of the real. For me, the two practices do not work in contrast, but together especially if we think of filmmakers who draw. Hence, it is only by considering the results of both practices that Grimshaw and Ravetz think of the possibility of a more radical view of anthropology, in which it can be considered a "practice of making images".

I understand drawing with the camera as the attitude of being attentive to process, observation, and experimentation. Something similar to drawing on paper, drawing the scene, framing it and placing it in a frame may be thought of as the lines that draw people and objects. A choice made from a subtle look that can see a person and notice the lines of the face that connects to the neck, which in turn meet with the lines that draw the clothes that this person wears. It may be a called an awareness to the anthropological gaze of these lines that trace reality. A relationship that slides between the ear and the eye (Trinh T. Minh-ha 2016), between the field diary and the camera.

The ethnographic return of contemporary art, a paradigm of quasi-anthropological art, according to Foster (2017), it is the artist's turn as an ethnographer, driven by the relative self-consciousness of the ethnographic method and by alterity, culture, context, interdisciplinarity, and the recent self-criticism of anthropology. Recently, at the 32nd São Paulo Art Biennial, "Incerteza Viva", several artists ${ }^{14}$ used the ethnographic method as a process and artistic method, as well as the curators' invitation of VNA to participate in the exhibition. Therefore, in my view, an artistic move by visual anthropology is necessary. Anthropological writing (through writing by words and/or images) is, above all, elaborated from relations with no hierarchy, just as we did in our creative video process. This difference can only be productive if brought into the arena of dialectical contradiction.

According to Schneider and Wright (2006), anthropology can benefit from a dialogue with artistic practice, regarding not only its contextualization forms, the juxtaposition between text and image, but also the idea of incompleteness: an open-ended way of creating artistic work that can encourage critical discussion about anthropology's tendency to produce texts that often lead to forced conclusions (2006:19). Anthropology, say the authors, must embrace incompleteness as "a positive norm for ethnographic practice", and perceive it as an "open and continuous archive" (2006: 20).

\section{The Process of Realizing Our Images}

The risk of sending yourself to meet the other without knowing what will happen is one of the fascinating things in life. In anthropology, this risk is constant, especially for me as I began my studies in the visual arts and found myself reading Malinowski and Strathern - avidly - to accompany my colleagues in the area of social sciences. The risk of throwing myself into the unknown and "the other," even while reading all the theoretical material, has accompanied me from the day I first saw Patricia in 2016 until 
the last day of field work in Ko'enju village, in July 2017, and even today, for example in writing this article - and in how we articulate our thoughts together.

I have some hypotheses for my insecurity in filming her and to honor her entire production of artistic thought. The problematization of the image of "the other" always disturbed me, even though I knew that my being there was sincere. I was concerned about the use of her image in the context of images of indigenous women who were (and are) represented in a stereotypical and violent way. The fact that I had never been to an indigenous village, or negotiated a filming process with anyone, that she was a filmmaker and co-author of the images, were also challenges, especially for my artistic work that I typically do alone. It was all new. At times it seemed that she was always suspicious, I think, especially in the light of some problems with the white principal at the school where she works. Add to this the circumstances surrounding my arrival to the village, coming from an unknown place, a state far from Rio Grande do Sul and Santa Catarina (states that are much closer to the Mbyá villages than Goiás), and without any "indication", in the sense that there was no one to introduce us, such as a research group or someone attached to her and her family who could mediate our relationship.

Only after a long time did Patrícia tell me her version of our first meeting, in a videoletter filmed during a film festival in which she participated as a jury member. We agreed to film Patricia telling a friend who was at the table with us, her impressions about the first time we met, and I did it with my cell phone:

Sophia said: I'm going to the village. I did not believe she would, right.

Then I said: that's fine. We were in Porto Alegre and then she said: oh, we'll meet. Then I would schedule it, and then I would hide from her, I avoided meeting with her. Actually, I thought she was going to be very annoying. I was not in the mood to talk to her. I only gave her the time that was leaving Porto Alegre, very late, thinking that she was going to give up, it was very cold. Our bus was leaving at $11 \mathrm{pm}$ at night. And to avoid talking too much to her, I went almost at the bus time, about ten o'clock ... Then, while boarding, Sophia was there and she appeared: "Hi". And she was full of clothes because of the cold ... Then I thought: Hmm, it's Sophia! (Patricia Ferreira Pará Yxapy, 2017)

And she grinned at the camera. As she was telling, Patricia stopped talking, turned to me, and said, "You're not listening, are you?" And she laughed. The story continued:

Then we met there and she said she was going to the village again and then I said okay, you can go. And after two days she went and she wrote: "I'm in San Miguel" and then I asked Ariel, "Shall we get her?" Then we went and we met there just like that. (Patricia Ferreira Pará Yxapy, 2017)

51 Later, Patrícia told me that she always hesitated to tell me this story precisely because she avoided me at first. The risk of this encounter with the other is probably more delicate from an anthropological point of view. Creating relationships is not easy, but keeping them and even getting rid of them is something more complex. Here, we will open a parenthesis to talk about some occasions that we lived to try to unveil the reasons that made me so insecure in filming or photographing her. In Ko'enju, we talked a few times about anthropology. Patrícia explained to me that for her and for the Guarani, anthropology is unnecessary because apparently, it is of no use since it says more about itself than of those who do it:

I do not mind the researchers here at home because the ones who strive to be here are you. I have always had to ask myself what are the actions and what are the parts of my culture. Where do my culture ends and the other begins? I think about it a lot when work and talk to someone from another culture. What made it easier for me to understand this, were the 
different practices and actions that we both follow in a given space, beliefs, values, and ways of acting on a particular subject or moment. That is, it gave me an understanding of things. I understood that we have our own identity and even though we are so equal - in my way of thinking, we are equal because we are two imperfect women in the imperfect world, two imperfect beings - and at the same time, we are also different. At the same time, we are equal and different. We had to adapt our conditions of existence and transform our realities. You came to my village and this was the fruit of a collective effort for the improvement of cultural and material values. I say collective effort because my family welcomed you since you were from the outside and we had an effort to try to understand you and you, Sophia, to understand us. And that was instrumental in understanding our moral and ethical values that guided our behaviors, our relationship, and our work. Understand how these values internalized us and how that drove our relationship in relation to each other. First, we accept the challenge of changing ourselves, of understanding ourselves. (Patricia Ferreira Pará Yxapy, 2018)

She just did not understand the researchers who did not share her field, that is, they did a solitary research without the involvement of other people. On this subject, I transcribe an excerpt from my field diary:

Patricia asked me what else I found different in the village and if this is my first time in an indigenous village. I said yes and she and Ariel told me that I am not an annoying person to have in the village, that I am independent and I do not spend all the time asking if I can do this or that. That I'm a nice person and that I'm not a researcher that acts like a village were a strange place. I make food, I insert myself into the activities ... Patricia gave me a paper to answer - a questionnaire Alice gave her to answer questions for Alice's TCC in teaching. She was an anthropologist. I asked what she was going to do with my answers and she said she was going to post it on a mural in the school for everyone to see. I was embarrassed, but I saw that it really was a good idea, after all, is not it more or less what I will do with my work? She said she was going to give this questionnaire to all juruá (whites) who go there to do research. (Sophia Pinheiro's field diary, Ko'enju, Brazil, May 2016).

We say all this because we think that this context is also reflected in the intimacy that we created and in my uncertainties in filming it, more precisely in deciding when to film it. That when, this available time, who dictated to me was her, after all, I was afraid to bother her in her daily activities. However, since she was in field work, as an anthropologist and as an artist who would create a work with her, when the filming equipment arrived, the negotiations and the processes became necessary, since we had previously filmed by cell phone and in a more spontaneous way - precious materials also. The negotiation process (it is worth stressing that negotiation is one of the devices of the documentary) was born from my first visit to the field and in the delimitations of the themes that we could develop. In 2016, my second time in the village and the time when we would begin filming the project, we decided to first film the making of Kaguijy ${ }^{15}$, that Elsa (her mother) would prepare and teach Gésica (her daughter) - this was the arrangement that seemed best to her - and then the other video-letter themed work.

The filming for the project was made in the last ten days that I was in the village; Patricia went through problems with health in her family and her work at school. She isolated herself and did not talk to me openly anymore. I was completely distressed and anxious because in three days I would go back to my house and we needed to film due to obligations with Fundo da Cultura. Until one day I went to talk to her and I started to cry. She took the camera and started filming me, asking why I was crying. I exposed my conflicts in being there, as a woman, as an anthropologist, as an artist and filming. She apologized for not being able to express what she was feeling, explained all the anguish 
that was inside her, and we began filming our conversation, which was unfolding and even covered some themes from the video-letters we had decided on before. We began the conversation by exposing our frailties, our fears, we talked about our relationship with our mothers, the absences of our parents and the diseases that somatized and affected our body. Then we talk about the relationship between Mbyá men and women, between Juruá body (white) and Mbyá body, child-rearing, sex, their relationship with school and non-indigenous, and even a letter to Gesésica in the future, containing some of Patricia's teachings for her:

I think above everything there was a cultural difference. And I do not think there could be a spiritual evolution for the two of us without our openness and understanding of our two worlds. That way it was possible to achieve our goal, at least for me. There was a kind of awareness of both of us, as human. Our elevation was very rapid to see the love, to see our interior and the reality of each other. And I think when we realized that truth we were welcomed by one another. Our love began to manifest in each of the things and in the environment itself. And so, the whole process for me was a spiritual search for an even more wonderful life, between us. (Patricia Ferreira Pará Yxapy, 2017)

In this conversation, we scheduled to go to Tamandua village over the weekend to see her relative who was sick and her family and make a filming of our bodies in the river there. In Tamanduá we could not film, because Patricia was even more distant and had to go to the house of prayer when she realized that she was sick. The Karai and the Kunha Karai ${ }^{16}$ took the pebbles out of Patricia's heart, which made her sick and strange. I was still distressed, even though I understood the whole situation. It was then that on her return to Ko'enju when we crossed the border between Argentina and Brazil, she saw the river and said: "Let's film here? I think we can bath and get naked here, what do you think?". At that moment, I understood everything she was explaining to me, about the importance of the moments when I was alone and silent, about empathy and coevalness (Fabian 2013). We did not film our bodies, but rather the images of her letter to Pero Vaz de Caminha and to the settlers, on the border, during dusk. That same day, on the way back to the village, she explained to me the nhe'e ("soul") of the word, about the sacred word and, again, about the importance of silence - the meditative state. The spirit is the word and it has substance.

In our filming arrangements and in our calendar, we had some incompatibilities, a double movement to fit one into the time of another. A complex set of mirrors in the recognition of the construction of the subject everywhere, in which one learns to see the world through what Bahri ( 2013: 683) calls the "logic of adjacency": "we would then understand women not as equals, but as neighbors, as 'neighboring dwellers' whose adjacency may become more meaningful ... we would read the world not as a single (in the sense of already being united), but as a whole".

Finally, through our subjective and collective conflicts and our ways of seeing the world, these two films - which I consider at the heart of our relationship starting from the video-letters - exemplify our investigative process in the accomplishment of the methodologies of this research. It is a risk, because getting into uncertainty may not work, but even what "did not work" in this research is important and was part of the process, as MacDougall ( 1975: 128) points out: "To conjecture that a film need not be an aesthetic or scientific performance: it can become the arena of an inquiry". In the presence of this investigative "field", the approach of images through drawing and camera precisely explores the approximation and tension of these methods. For Grimshaw and Ravetz (2015: 9) "underpinning their approach is an opposition between 
the pencil and the camera, between 'making' and 'taking', between restrictive and generative modes of inquiry" . It is in this place between me and the other, between observing the real and inventing the real, from pencil to camera, between making and expecting to happen and between uncertainties, this is where our relationship narrows and behaves like two women who can generate life - aesthetic and political possibilities through video-letters. It is in this place that Patrícia finds herself as a fold in time, past, present and future. A time that I learned to have.

\section{The Videography of the Encounter. Becoming Someone and Making Films} believe that there are many worlds and I am happy to be able to inhabit one of them with Patricia. In our process I understood myself a little more, I respected and understood her in the divergent and convergent points, and I created a new state within the human. The truest thing our work can offer is the correctness of our images. We bring to the fore an unequivocal question discussed in anthropology, visual arts, and cinema that being "women's issues": the home, motherhood, woman as a wife - but in the subjective bias..There are many reports of men as the privileged interlocutors of colonization. The masculine point of view is prevalent in the social sciences and in the colonization process, evidence that also corroborates to the struggle for protagonism and the anthropological erasure of indigenous women. They were relegated to the domestic space, due to fear and the political and cultural structure of the South American indigenous populations (Lasmar, 1999), while men were agents of contact and socially active, according to most researcher's analysis. These factors may have encouraged the analytical privilege of the masculine perspective and contributed to the devaluation of female roles in these indigenous populations, as well as to the universal devaluation of the domestic domain (Overing, 1986). Since indigenous women did not 
have time or space to speak, their representation was then attributed to indigenous men and colonizers, limiting their social experiences and trajectories.

So, we close with one of the videos that Patricia wanted to make of me, killing a chicken. She wanted to film me and teach me how to kill a chicken. Here we show a piece of the whole process that lasted a whole day, from killing it, taking the feathers that are used for crafts, cutting and knowing which cut is best and who can eat which parts of the chicken (for example, girls who are at the onset of menstruation cannot eat the chicken's feet). Patricia said, "This was a test for you, to see if you could actually be my friend."

This media file cannot be displayed. Please refer to the online document http://

VIDEO_LINK= https://vimeo.com/302443789/c4588d55f8

Patricia tells the whites, in the video-letter that we made at the border: "I think you wanted us to not exist", in the end, it is also meant for me. But still, we are, Patricia and Sophia, a "white woman" and "indigenous woman" creating an artistic work together, and yes, that can be a weapon to strike a blow to every ethnocentric, ethnicized, male chauvinist. We filmed marking our space as women. And it was an experience of our feminity. A dip into "being imperfect", according to Mbyá-Guarani spirituality. As human beings, we are inherently imperfect to the eyes of Nhanderu, Nhandexy (spiritual father and mother) and other Guarani deities. Before the camera, we fictionalize reality, but we also put our most intimate humanity. We wanted to let our relationship, created through the images, guide us.

\section{BIBLIOGRAPHY}

\section{Books and articles}

Bahri, Deepika. 2013. Feminismo e/no pós-colonialismo. Estudos Feministas 21(2): 659-688.

Bavcar, Evgen. 2003. Memória do Brasil. São Paulo: Cosac \& Naify.

Berger, John. 2005. Berger on Drawing. Aghabullogue: Occasional Press.

Cardoso Vale, Glaura, Carla Italiano and Júnia Torres (eds.). 2015. Mostra Olhar: Um Ato de Resistência. Catalogue published in conjunction with film festival Forum.Doc.BH 2015, Belo Horizonte, Brazil. http://www.forumdoc.org.br/wp-content/uploads/2015/11/ Catalogo_Vol2_site.pdf (accessed 14 August, 2020).

Carelli, Vincent. 2017. Dossiê Andrea Tonacci. Created by Abraccine. https://abraccine.org/ 2017/01/22/carelli-tonacci. (accessed 14 August, 2020).

Carelli, Vincent. 2011. Um novo olhar, uma nova imagem. In: CARVALHO, Ana; CARVALHO, Ernesto; CARELLI, Vincent (Org.). Vídeo nas Aldeias: 25 anos. São Paulo: Itaú: Natura. 42-51. 
Caiuby Novaes, Sylvia. 2012. A construção de imagens na pesquisa de campo em Antropologia. Iluminuras, Porto Alegre. 13 (31): 11-29.

Clifford, James. 2008. A experiência etnográfica: antropologia e literatura do século XX. (Tradução de José Reginaldo Santos Gonçalves.) Rio de Janeiro: Ed. UFRJ.

Fabian, Johannes. 2001. Anthropology With Attitude. Redwood City, CA: Stanford University Press.

Fabian, Johannes. 2013. o tempo e o outro: como o antropológo estabelece seu objeto. Petrópolis, RJ: Vozes.

Flusser, Vilém. 1985. Filosofia da caixa preta: ensaios para uma futura filosofia da fotografia. São Paulo: Hucitec.

Foster, Hal. $O$ artista como etnógrafo. 2017. In: O retorno do real: a vanguarda no final do século XX. São Paulo: Ubu. 159-186.

Grimshaw, Ann and Amanda Ravetz. 2015. Drawing with a Camera? Ethnographic Film and Transformative Anthropology. Journal of the Royal Anthropological Institute 21(2): 55-275.

Ingold, Tim. 2013. Making Anthropology, Archaeology, Art and Architecture. London: Routledge.

Kuschnir, Karina. A antropologia pelo desenho: experiências visuais e etnográficas. Cadernos de Arte e Antropologia, Salvador, 5 (2). http://cadernosaa.revues.org/1095. (accessed 16 August, 2020)

Lasmar, Cristiane. 1999. Mulheres indígenas: representações. Estudos Feministas, Florianópolis, 7 (1 and 2): 143-156.

MacDougall, David. 1975. Beyond Observational Cinema. In Principles of Visual Anthropology. Paul Hockings, ed. pp. 115-132. New York, NY: Mouton de Gruyter.

Marcus, George. 1995. E. Ethnography in/of the World System: The Emergence of Multi-sited Ethnography. Annual Review of Anthropology 24: 95-117.

McLuhan, Marshall. 1974. Os meios de comunicação como extensões do homem. (Tradução de Décio Pignatari). São Paulo: Cultrix.

Migliorin, Cezar. 2014. O ensino de cinema e a experiência do filme-carta. E-compós - Revista da Associação Nacional dos Programas de Pós-Graduação em Comunicação, Brasília, DF, 17 (1) https://www.e-compos.org.br/e-compos/article/view/1045/758. (accessed 14 August, 2020).

Migliorin, Cezar. 2015. Inevitavelmente cinema: educação, política e mafuá. Rio de Janeiro: Beco _Overing, Joanna. 1986. Men Control Women? The Catch-22 in Gender Analysis. International Journal of Moral and Social Studies 1(2): 135-56.

Pinheiro, Sophia Ferreira. 2017. A imagem como arma: a trajetória da cineasta indígena Patrícia Ferreira Pará Yxapy. 2017. 283 f. Dissertação (Mestrado em Antropologia Social) - Universidade Federal de Goiás, Goiânia.

Rouch, Jean. 1973. Testimony transcript at the annual meeting of the Brazilian Society for the Progress of Science - July 1973. In: Avellar, José Carlos. Le maitre fou cinema-verité [material no longer available on the internet]

Ruiz, Coraci B. 2009. Documentário-dispositivo e vídeo-cartas: aproximações. Dissertação (Mestrado em Artes) - Instituto de Artes, Universidade Estadual de Canpinas, Campinas.

Samain, Etienne. 2016. Vestígios de um diário fotográfico. GIS - Gesto, Imagem e Som 2(1): 214 -228.

Sautchuk, Carlos E. 2013. Cine-arma: a poiesis de filmar e pescar. Brasília, DF: Universidade de Brasília. 
Schneider, Arnd and Wright, Christopher (Org.). 2006. Contemporary art and anthropology. Oxford: Berg.

Taussig, Michael. 2011. I Swear I Saw This: Drawings in Fieldwork Notebooks, Namely My Own. Chicago, IL: The University of Chicago Press.

Trinh, Minh-ha T. 2016. Olho mecânico, ouvido eletrônico, e a atração da autenticidade. In A experiência da imagem na etnografia. Andréa Barbosa et al. eds. São Paulo: Terceiro Nome. 9-18.

Veiga, Roberta and Italiano, Carla. 2015. O diário como dispositivo e o efeito do eu no cinema: Akerman e Perlov. Contemporanea, revista de comunicação e cultura, Salvador. 13 (3). 708-724.

\section{Films}

Akbari, Mania and Marks Cousins, dir. 2014. Life May Be. UK and Iran. 80min. Trailer on on YouTube https://www.youtube.com/watch?v=Ixwy3TOva38 (accessed 14 August, 2020)

Akerman, Chantal, dir. 1977. News from Home. France. 90 min.

Carelli, Vincent, Patricia Ferreira Pará Yxapy, Ariel Duarte Ortega, and Ernesto de Carvalho, dir. 2012. Tava, the Stone House. Video nas Aldeias (production). Brazil. 78 min.

Carelli, Vicent, Ernesto de Carvalho, Tita, dir. 2016. Martírio. Video Nas Aldeias (production). Brazil. 162 min.

de Andrade, Jonathas, dit. 2016. 0 peixe. Brazil. 37 min.

Godard, Jean-Luc, dir. 1972. Letter to Jane. France. $52 \mathrm{~min}$.

Hatoum, Mona, dir. 1988. Measures of Distance. UK. 15 min.

Kiarostami, Abbas and Victor Erice, dir. 2007. Victor Erice/Abbas Kiarostami: Correspondances. Spain and Iran. $96 \mathrm{~min}$.

Kramer, Robert, dir. 1991. Dear Doc. France. 35 min.

Marker, Chris, dir. 1957 Lettre de Sibérie. France. 60 min.

Mekas, Jonas, dir. 2011. Correspondance Mekas - J. L. Guerin. France and Spain. 90 min.

Pawels, Eric, dir. 2000. Carta de um cineasta a sua filha. France. $47 \mathrm{~min}$.

Perlov, David, dir. 1983. Diary 1973-1983. Israel. 300 min.

Pinheiro, Sophia and Patrícia Ferreira Pará Yxapy, dir. 2018. Teko Haxy - Being Imperfect.

Experimental Documentary. Brazil. $39 \mathrm{~min}$.

Queiroz, Armando and Almires Martins. 2009. video installation Ymá Nhandehetama (Brazil 2009), by the artist and the native Guarani. https://vimeo.com/117503392 (accessed 14 August, 2020)

Ruiz, Coraci and Julio Mato, dir. 2012. Cartas para Angola. Brazil. 78 min.

Trinh, T. Minh-Ha, dir. 1982. Reassemblage - From the Firelight to the Screen. USA. 40 min. https:// vimeo.com/276997464

Txicão, Natuyu Yuwipó, Karané Ikpeng and Kumaré Ikpeng, dir. 2001. Das Crianças Ikpeng Para o Mundo. Video nas Aldeias (production). Brazil. 35 min. https://www.youtube.com/watch? $\mathrm{v}=\mathrm{MNI}$ HjdfvJg, (accessed 14 August, 2020).

Varda, Agnès, dir. 1982. Ulysses. France. 22 min.

Wagner, Barbara and Benjamin de Burca, dir. 2016. You Are Seeing Things. Brazil. 16 min.

Websites 
Vídeo nas Aldeias http://videonasaldeias.org.br/2009/index.php (accessed 14 August, 2020).

\section{Exhibitions}

"32nd Bienal de São Paulo - Incerteza Viva" ("Living Uncertainty"), Collective Exhibition, Bienal Pavilion from September 7 to December 11, 2016 Curator: Jochen Volz, Co-curators: Gabi Ngcobo, Júlia Rebouças, Lars Bang Larsen and Sofía Olascoaga, São Paulo-São Paulo, Brazil.

"ReAntropofagia", Collective Exhibition of contemporary Brazilian indigenous artists. Curator: Denilson Baniwa and Pedro Gradella, Arts Center of Universidade Federal Fluminense, from April 24, 2019 to May 26, 2019, Niterói-Rio de Janeiro, Brazil.

\section{NOTES}

1. The dissertation "The image as a weapon: the trajectory of indigenous filmmaker Patrícia Ferreira Pará Yxapy" is available for download on the website of the Central Library of the Universidade Federal de Goiás < https://repositorio.bc.ufg.br/tede/handle/tede/7897 > Accessed 17/5//2018.

2. Village in São Miguel das Missões, Rio Grande do Sul, Brazil.

3. The film was assembled by Tita (Tatiana Soares de Almeida), an editor and one of the creative directors of the video project Nas Aldeias. Recently Tita co-directed and edited the important film Martírio (Brazil 2016) (Vicent Carelli, Tita and Ernesto de Carvalho 2016).

4. In this film, the Vietnamese filmmaker based in the United States reflects on the difficulty of constructing objective discourses on cultural manifestations. Available at: https://vimeo.com/ 276997464. Accessed 15 August, 2020.

5. When speaking of aim, Mcluhan (1974: 383) states that "Good aim is not the gift of the native or the man of the forest, but of the literate settler", something that we completely refute and criticize for it's ethnocentricism. However, we understand that the assimilations and concepts between aim/perspective and gun/camera/eye are relevant to the hypotheses raised in this article.

6. Created in 1986, Video Nas Aldeias (VNA) is a trail-blazing project for indigenous audiovisual production in Brazil. The objective of the project from the outset was to support the struggles of indigenous peoples to strengthen their identities and their territorial and cultural heritage, through audiovisual resources and a shared production with the indigenous peoples with whom the VNA works. Project's website: http://videonasaldeias.org.br/2009 (accessed 14 August, 2020).

7. National Indian Foundation (FUNAI), Brazil.

8. "Mostra Olhar: Um Ato de Resistência", round table / meeting "Current perspectives for the existence of indigenous worlds and cinemas" during Forum.Doc.BH 2015, Belo Horizonte, Brazil. Catalog available: http://www.forumdoc.org.br/wp-content/uploads/2015/11/ Catalogo_Vol2_site.pdf (accessed 14 August, 2020).

9. The modernist anthropophagy of cultural appropriation. The ingestion of the culture of images with the aim of seizing their forces and their energies. Communicative, aesthetic and intercultural powers. A reframing of Brazilian Modernist Anthropophagy. A process of ReAnthropophagy: "anthropophagy is now the devouring of everything that exists without using French cutlery", as stated by Denilson Baniwa, Brazilian indigenous artist of the Baniwa people. Denilson was also curator of the exhibition ReAntropofagia at the Arts Center of Universidade Federal Fluminense, from April 24, 2019 to May 26, 2019, this excerpt is part of the opening text of the exhibition (not available on the internet). 
10. "Dossiê Andrea Tonacci" created by Abraccine. https://abraccine.org/2017/01/22/carellitonacci. (accessed 14 August, 2020).

11. Available at: https://vimeo.com/117503392 (accessed 14 August, 2020).

12. Goiás State Fund for Arts and Culture

13. The city where I lived, the capital of the state of Goiás, Brazil.

14. Among them, I highlight Jonathas de Andrade with the film 0 peixe (Brazil 2016), situated in a hybrid territory between documentary and fiction, that dialogues with the ethnographic tradition of the audiovisual; I also point out Barbara Wagner with the film, "You are Seeing Things" (Brazil 2016), which presents an incursion into the musical and audiovisual world of the effervescent playful scene of the periphery of Recife. This work of ethnofiction creates a video clip with real characters and uses a sample of the popular whole to promote a reflection on the world of consumption and social mobility in the peripheries, giving voice and expression to the subjects themselves.

15. Sacred fermented drink made from avaxí ("corn") made only by women. Used to feed the soul.

16. Spirital leader, what the Mbya-guarani call their shamans, Karaí referring to men and Kunhã Karai to women.

\section{ABSTRACTS}

In this article, we will explore a relationship between Patrícia Ferreira Pará Yxapy and Sophia Pinheiro through image and filmmaking. A videography of a poetic encounter between two women, one indigenous and other non-indigenous, using visual anthropology in a delicate sense. As for methodological process, this is research made with a visual ethnography that thinks of the power of images as the production of meaning and collaboration. It was from this fissure that the artists made an ethnographic experience of video-letters - they constitute exchanges of videographic messages of the most diverse subjects. In this project, they exist between Patricia and Sophia, in the form of feminine and subjective questions, to show the relationship between with images and sounds. As Patricia says: "What I put out was inside me."

Dans cet article, nous exposerons les processus filmiques et imagétiques entre Patrícia Ferreira et Sophia Pinheiro. Une vidéographie de la rencontre poétique entre deux femmes, l'une indigène et l'autre non autochtone, utilisant une anthropologie rendue possible par des images au sens délicat. Quant au processus méthodologique, il s'agit d'une recherche faite avec une ethnographie visuelle qui pense à la puissance des images en tant que production de sens et de collaboration. C'est à partir de cette fissure que les artistes ont eu l'expérience ethnographique des vidéo-lettres - qui constituent en échanges de messages vidéographiques en divers thèmes. Ces vidéo-lettres existent dans le but de montrer avec images et sons la relation entre Sophia et Patricia et aussi leurs questions féminines et subjectives. Comme dit Patricia: “ce que j'ai mis dehors était en moi".

En este artículo, expondremos los procesos de intercambio de películas e imágenes que tuvieron lugar entre Patrícia Ferreira y Sophia Pinheiro. Una videografía del encuentro poético entre dos mujeres, una indígena y otra no indígena, utilizando una antropología hecha posible con imágenes en un sentido delicado. En cuanto al proceso metodológico, se trata de una 
investigación realizada a través de una etnografía visual que piensa en el poder de las imágenes como producción de sentido y colaboración. Fue a partir de esta fisura que las artistas hicieron una experiencia etnográfica de video-cartas, que constituyen intercambios de mensajes videográficos de los más diversos temas. En este proyecto, estas imágenes existen entre Patricia y Sophia en forma de preguntas femeninas y subjetivas para mostrar la relación entre imágenes y sonidos. Como dice Patricia: "Lo que mostré estaba dentro de mí".

\section{INDEX}

Palabras claves: mujer indígena, cine indígena, cineasta indígena, video-cartas, antropología visual, artistas mujeres, imágenes

Mots-clés: femme autochtone, cinéma autochtone, cinéaste autochtone, vidéo-lettres, anthropologie visuelle, femmes artistes, imag

Keywords: indigenous woman, indigenous cinema, indigenous filmmaker, video-letters, visual anthropology, women artists, images.

\section{AUTHORS}

\section{SOPHIA FERREIRA PINHEIRO}

Universidade Federal Fluminense, Brazil

sophiaxpinheir@gmail.com

\section{PATRÍCIA FERREIRA PARÁ YXAPY}

Brazil

yxapy.patri@gmail.com 